\title{
The Quadrature of Stone
}

\author{
Jonathan Lamb
}

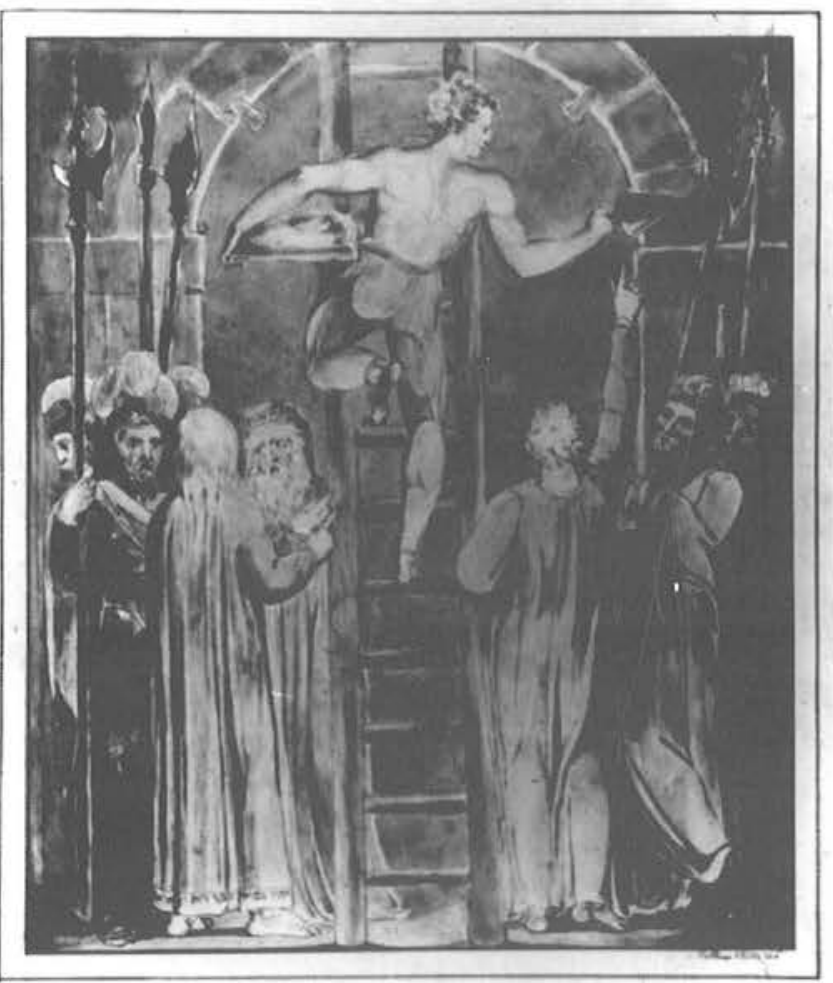

Setting the Stone

In his book The Roman Stonecutter Giancarlo Susini informs us that the quadratarius was the mason responsible for 'the totality of operations involved in the execution of an epigraphic monument. ${ }^{1}$ That is to say, he was responsible for the accurate cutting and dressing of the stone, and for the subsequent tracing and engraving of the letters it was to bear. The name assigned to this expert seems intended to embrace the four key stages of monumental inscription, as well perhaps as the four faces of the shaped block or stele. Certainly he had four tools for the job: scalpum, malleus, asciae and dolabrae (p. 25). In this paper I want to explore the quadriform arrangements that monumental stone seems to require, and to show how analogous configurations of stone make their way into myth, and then into the monumental sculpture of 18 th century Britain.

The relation between writing and stones is as old as writing itself, a fact evident in their joint etymologies. Monument is a term embracing stone markers and inscribed documents. As well as its more familiar meaning of carved or engraved stone, the OED gives 'written 
memorial' as one its definitions for monument, and in its corrupt form of muniment the word refers specifically to historical documents such as genealogies, title-deeds, and marriage certificates - the sort of manuscript stili to be found in the muniment rooms of great country houses. In Greek the same ambiguity is to be found in the word sema, which means both funerary monument and inscribed sign. It suggests that the arts of writing and rearing monuments were coeval ${ }^{2}$. An 18th century etymologist called George Costard traced the word hermeneut and the name Hermes to the heaps of stones, called arma in Chaldean, which used to mark the boundaries of land. In Greece, Costard maintains, they first changed these Heaps into single stones, then carved a Man's head upon them; and at length shaped and ornamented them with greater Art and Contrivance ... . The Decoration made the original of the Practise forgot, so that the Stones themselves were called ERMAI, as if they were the Statues of Hermes.' By a species of synecdoche the sense of heap is preserved in the deceitful facility with language which is supposed to be the characteristic of Hermes ('speaking with Fluency and Eloquence ... is, in a metaphorical sense. The heaping up of words'.) $)^{3}$ Likewise a hermeneut is one who shows skill in dividing and distinguishing between the words that make up the heap.

Whether Costard is right in his speculations, Hermes is the god credited with the invention of writing, his name is reducible to herma, or rock, and he is the god responsible for the dead, as well as for doorways and crossroads. Consistent with this combination of the written and the stony, Hermes' sacred number is four. John Kerrigan calls him the god of the tetraglyph ${ }^{4}$; and the tetraglyph which interests me is the four-sided pun emerging from sema: sema the stone and sema the sign; soma the body concealed and commemorated by the sema: and semen, the reproductive principle, or seed, of the soma that is either abetted or thwarted by the sema. So I shall be looking for a quadrature that will include stone, writing, the body, and the power of reproduction.

In various incomplete forms the tetraglyph can be detected taking shape in the oldest Greek 
funerary structures. The intimate connection between the stone and the sign is intended to exert a magical potency over the forces of decay and oblivion; and to accomplish this the stone must carry the proper name of the person who is not to be forgotten: ' $\mathrm{I}$ am the monument of Phrasikleia.' 'I am the memorial of Glaucos.' 'This stone, close to the road, calls itself Prokleidas. ${ }^{5}$ Before the latter half of the fifth century $\mathrm{BC}$ these stones address the public on the highway in the first person, establishing literally an identity between the material object and the person it commemorates; and this identity takes on a voice when the traveller who has paused to read, spells out the inscription aloud, as early Greek readers had to do if the letters were to make any sense to them. In a remarkably vivid example of the figure of prosopopeia, the reader of the stele or column gives voice, name and face to the dead - an effect not possible with later inscriptions done in the third person. The inscribed stones by the wayside are like flowers, then, fertilised by the voice of the roaming bee-like reader who confronts them and proclaims their name and quality. To face the stone, sema, is simultaneously to deliver its written message, sema. And all this is possible because the reader allows his/her own body, or soma, to be instrument through which the sentiments of the buried body may be ventriloquised. In the case of Epimenides, who had his last words tattooed on his corpse, soma is even more directly transformed into sema.

The illusion generated by the stone is that it speaks for the dead, and sometimes this speaking is acknowledged to be a substitutive act, a speaking on behalf of the dead. Here the stone

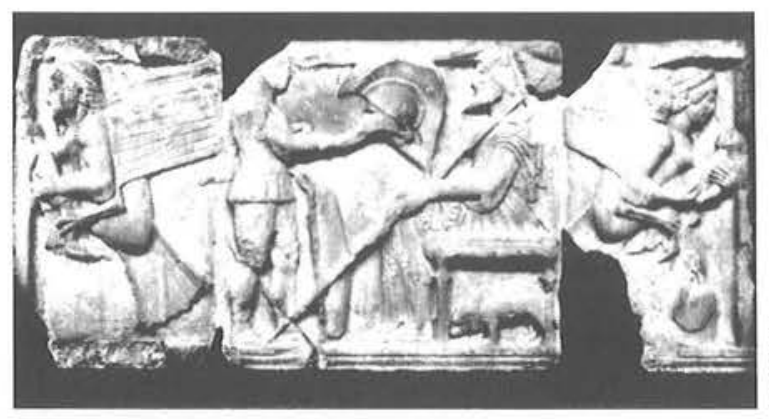

Tomb of the Harpies (Souls borne aloft by winged females.) 
bears the family name, the name of the father to whom it stands in the relation of child. The stone follows the Greek custom of naming the child with the epithet of the father or the grandfather, like the name Telemachos which refers to Odysseus, who fights a long way off. In an Orphic poem Phoibos gives Heleneus a stone which they treat like a child, dressing it and washing it. ${ }^{6}$ This renders equivocal the phrase, 'to rear a column.' Like the Greeks, Absalom reared a pillar instead of a child, 'for he said I have no son to keep my name in remembrance: and he called the pillar after his own name' (II Sam. 18). This seminal function of the stone is understood by Jesper Svenbro to establish a set of family links between the inscriber, the inscription and the reader of the stone: the writer is the father, the writing is the daughter, and the reader is the son-in-law. By applying this epitaphic structure of descent and alliance to Sappho's famous Ode, known as fragment 31, where she records the symptoms of jealousy as she watches her lover being courted by a man, Svenbro discovers the pathos of an epitaph in reverse. What is dramatised here, he suggests, is not a literal scene of jealousy, or even the spelling out of loss, but the agony of the writer of an inscription: Sappho's voice breaks and her body shatters as she beholds the lover/reader absorb the poem she has written, her daughter as it were, by giving the letters voice: 'All day, he sits before you face to face ... if you should speak he hears.' Like all writers of inscriptions, she foretells her own absence from the scene of reading: eavesdropping upon the strange intimacy between text and reader when, the one turning to the other, they meet face to face in order to continue the line of descent in flesh or in stone.

Possibly it is this specifically maternal relation between the memorialising agent and the mute (infans) object of grief (who nevertheless may recover voice by means of the female parent's intervention) that accounts for the prominence of bare-breasted females on ancient tombs. On Greek funerary urns and sarcophagi women bare their bosoms in the agony of grief. On one of the most ancient steles, the tomb of the harpies, the souls of the deceased are borne heaven-wards by large-breasted birdwomen, suggesting a primordial connection 
between the work of mourning and the labour of nursing?

Now let us see whether this quadriform arrangement of stone, writing (for which we must suppose a writer as well as a reader,) body, and reproductive power can be applied to some archetypal stories. There are two myths in which stone plays a predominant part - the story of Niobe, where a woman is turned to stone; and the story of the Medusa, where a woman turns other people to stone. Niobe, wife of the Amphion, is punished by Artemis and Apollo for the maternal pride she shows in her fourteen children. Her punishment is to see them all die. She returns to her father's house at Sisyphus, where Zeus grants her prayer, and she is

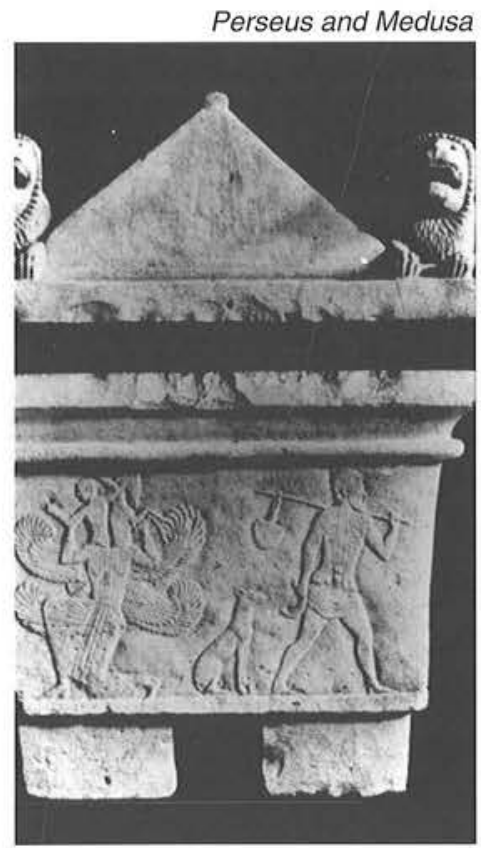
turned to a stone that weeps forever. In the second story, Perseus is challenged by Polydectes, ruler of Sesiphos, to bring back a Gorgon's head. Using his bronze shield as a mirror, he manages to cut off the head of Medusa, the only mortal one of the three Gorgons, without being transformed to stone by the sight of her face. He carries back her head, and by fixing it to his shield is able to turn all his enemies to stone, including Polydectes himself, who has been harassing his mother Danae.

At first sight neither story offers very much to go on. In his translation of Ovid's Metamorphoses, where Niobe's story is told together with a list of the petrifying feats accomplished by Perseus, George Sandys inserts an interesting note on Niobe. He says that she lost her children in a plague that raged at Thebes, and that her transformation into marble is a confounding of the symptoms of her immovable sorrow, which she indulged in the stony landscape of Sisyphus (a 'Place full of rocks and broken precipices,') with the sema surmounted by her own image, carved by Praxiteles, which she raised to her dead children. He mentions also the inscription on this monument, preserved by Ausonius: 
I liv'd; became a stone: now polish'd

By thee Praxiteles, no longer dead.

All by thy art restor'd; sence wants alone:

And I, when I provokt the Gods, had none. ${ }^{8}$

and adds Ausonius' enigmatic commentary on it:

This is a sepulcher without a body:

A body this without a sepulcher:

Both sepulcher and body unto her.

Using Svenbro's insights, it is possible to read Niobe's sema, as I think Ausonius is reading it, as a speaking image-'no longer dead' once the sense of the written stone is supplied by the reader. The sema as stone no longer can be said to conceal a cadaver if the sema as sign is activated by the reading voice; therefore the sema and the soma are the same thing ('both sepulcher and body unto her.') Whether this re-establishes some vestige of maternal descent is open to doubt, since the place of the children in the monumental structure is unclear, but the figurative reconstitution of Niobe would suggest that there is room for it. Here at any rate is the basis of an equivocation that operates at the edge of so many monuments of grieving women in the 18th century, where consorts in various attitudes of distress 'turn to stone' before the tombs or images of their husbands: 'A marble imag'd matron on her knees/ Half-wasted, like a Niobe in tears.' Richard Westmacott's Biddulph monument (1814) has the Niobe figure (Charlotte Biddulph) flanked by the inscription to her spouse, which seems to have petrified her in the act of reading it. The very medium of the monument allows the equivoke (a woman turned to stone in the gesture of turning towards a stone to decipher it) a dramatic immediacy. This brings into play the sexual element of the loss, or what Freud calls in his essay on mourning 'the libidinal position without an object.' This implication already had been formalised by Westmacott in the Brownlow monument, where the female mourns her loss beneath a broken column, conventionally an icon of childlessness; but in his tomb-sculpture, The Distressed Mother, exhibited at the Royal Academy in 1822 to huge 


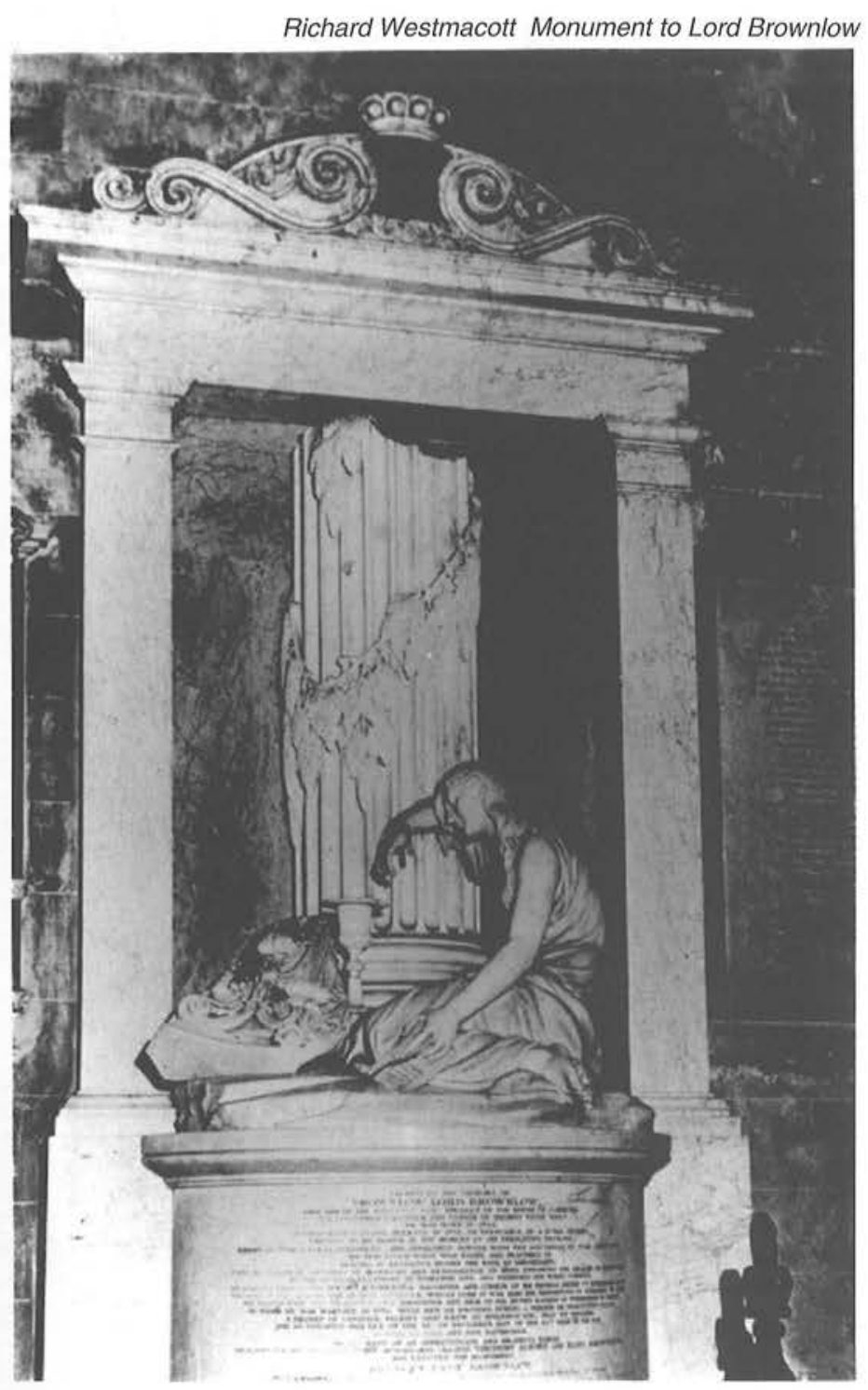

acclaim, Westmacott restores the Niobe role to the wife as nursing mother, who is turned into stone as she turns to the infant in her arms, the fruit of lawful embraces. Here the primordial link between the mother and child, evident in the tomb of the harpies as well as the myth of Niobe and her children, is partly re-established, insofar as the infant is the medium (but not the object) of maternal grief. In one of the most celebrated paintings of the later eighteenth century, Wright of Derby's The Dead Soldier, exhibited at the Royal Academy in 1789, the mother mourns her husband, dead at her feet, while leaning over the baby at her breast-an image widely reproduced that drew tears from William Hayley and Robert Burns, among others.

Let us get back to Perseus and the Medusa. Apollodorus reports that Perseus was conducted to the Gorgons' den by Hermes, who gave him a sickle of adamant with which to decapitate the monster. He reports also that Perseus accidentally slew his father Acrisius with a stone. It is impossible to think of this myth without Freud's commentary on it, where he associates the snaky locks of Medusa with the fetishised pubic hair of the female, and her 
terrifying face as the threat of castration held forth to the male in the sight of the female genitals, a threat that turns him to stone with fear (or possibly 'stones' him in the sense of removing his stones or testicles,) at the same time as it excites him and, with a reassuring stiffness, reminds him that his stones are still there. Doubtless there are many ways of reading the myth, and the two Freudian aspects of stone suggest some sort of Oedipal scenario that leaves a mother sexually vulnerable, and a father slain, all owing to the actions of the son; but if we stick to the model of the sema, then the stone weapon given to Perseus by Hermes suggests some sort of link between the somatic violence that is to be directed at the Gorgon and a semiotic function. The link is not to be found in the weapon but in the bronze mirror of the shield, which first reflects the living head and then frames the dead one. It is a sort of portable sema, a meeting point for the representation of life and death. So many pictures, Caravaggio's in particular, are repetitions of the shield, putting the artist in Perseus' place and the viewer in his victim's. In his verses 'On the Medusa of Leonardo da Vinci,' Shelley writes, 'Death has met life, but there is life in death,' and as if to emphasise the twoway traffic between flesh and stone in this picture which characterises all good face-to-face readings of tomb inscriptions, he draws attention to the spectator's substitute in the canvas, a toad, (a creature supposed to carry a stone in its forehead,) sitting on a rock and gazing at the Gorgonian head that is itself becoming indistinguishable from the wet stones it rests upon. The remarkable second stanza begins:

Yet it is less the horror than the grace Which turns the gazer's spirit into stone, Whereon the lineaments of that dead face Are graven, till the characters be grown Into itself, and thought no more can trace.

He seems to imagine the gazer and the Medusa joined in one indecipherable, involuted petroglyph, a plenary sign meaning nothing but itself. The closest I can get to an analogue 
of what Shelley is conceiving here, is an allusion in Roger Caillois' Pierres to the autoglyphs mentioned by Aretazus in his History of Phrygia, stones carrying the self-engraved image of the mother of the gods. 'If a eunuch were to come across such a stone,' he adds, 'he would no longer mourn his lost testicles, but endure his condition ever afterwards with great constancy and cheerfulness.'(20) In this light both the semic and the seminal elements of the Medusa point towards a more negative interpretation than Freud's double intuition of castration and puissance. Possibly the despatching of the female figure under Hermes' superintendency is, as Neil Hertz has suggested, a mythic representation of the abjection of the mother and of the location of the subject in language. ${ }^{9}$ Jacques Lacan hypothesises the discovery of something like a sema or an autoglyph in order to explain how this location is made:

\footnotetext{
'Suppose that in the desert you find a stone covered with hieroglyphics. You do not doubt for a moment that, behind them, there was a subject who wrote them. But it is an error to believe that each signifier is addressed to you-this is proved by the fact that you cannot understand any of it. On the other hand you define them as signifiers, by the fact that you are sure that each of these signifiers is related to each of the others. And it is this that is at issue with the relation between the subject and the field of the Other. The subject is born in so far as the signifier emerges in the field of the Other. But, by this very fact, this subject-which was previously nothing if not a subject coming into beingsolidifies into a signifier. ${ }^{\prime 10}$
}

In one sense this is an account of how an aspiring reader turns into what he reads, how the gazer at the stone turns into stone, and how, like the Phrygian eunuch, the subject reconciles himself to the loss (the stoning) that constitutes him as a subject. This is the doubtful triumph Hermes offers Perseus. In another sense, it sets the scene for Oedipus' tussle with a large-breasted female figure over an enigmatic text which he will both successfully interpret and by which he will be fatally misled, and as it were stoned.

Let us see if we can get any further with the quadrature of the stone by means of the myth 
that introduces Lacan's remarks on the hieroglyphic stone and which forms the focus of Freud's Beyond the Pleasure Principle, namely Aristophanes' contribution to the discussion of love in Plato's Symposium. You know his story of our ancestors, the primitive whole creatures with eight limbs and two heads, who were sliced in two by Zeus for trying to unseat the gods. Ever since then the two halves have tried to reunite by means of sexual coupling. Aristophanes adds this warning to his fable: 'We have reason to fear that if we do not behave ourselves in the sight of heaven, we may be split in two again ... and go about like the people represented in profile on tombstones, sawn in two vertically down the line of our noses.'(64) The reduction from the unitary creature to the quartered fragment is figured as a shift from soma to sema, from living flesh to senseless stone, from the rounded lineaments of constantly satisfied desire to a bare effigy in bas relief. The incision made by the parental knife in fact draws two boundaries: first of all between the self-sufficient body and its divided, seminating parts, and then between the desiring halves and the stony quarters. So here we have a quadrature in sequence, ending at the tomb, assuming that the quartered figures make up a sema both as sign and stone. 'In this way,' says Lacan, 'I explain the essential affinity of every drive with the zone of death.'(199). Freud's interpretation of the myth is much the same in taking the sexual drive to be the colouring of a deeper desire to return to an earlier, inanimate state of things. In Freud's archaeology this is the state of stone, the pre-existence of the protiston in the rock-like form from which it was torn, in a primordial shock 'of whose nature we can form no conception,'(332) as quivering flesh. In this reading stone is the destination as well as the origin of all living things; but the degree of obliquity between these two points, which is the measure of life itself, depends on the amount of 'crust' the living splinter can accommodate without actually killing itself: 'Its outermost surface ceases to have the structure proper to living matter, and becomes to some degree inorganic and thenceforward functions as a special envelope.' The fragments of soma who have the best time are those whose line of descent from stone to stone is complicated by a strategic addition of sema. In the Swift-Sheridan version of Aristophanes this gives extra voice to what 
was always a 'PUN of flesh and blood,' for 'When the thing was split in twain/ Why then it PUNN'D as much again.' This is like the voice the stone of a Greek sema acquires when it is properly read, face to face. It is precisely this voice, together with the mixture of flesh and stone which generates it, that is lacking from the Medusa story, but which is recovered by Niobe and which seems obscurely to be guaranteed by the maternal autoglyph that consoles the cut creature.

We have already seen how some British tombs and memorials from the 18th century abbreviate the circuit from stone to stone as a pun on 'turning to stone.' The circuit may be interpreted positively as a restoration of voice by means of a primordial reconnection of the mute form of loss with its mother. On the other hand it can be understood as a short-sighted gendering of mourning roles (the man dies, the woman weeps.) This ambivalent positioning of the tomb sculpture between restoration and oppression is something of which funerary verse itself seems aware, dramatising it as hostility between the stone and its reader, based on pointless repetition. A reader who says things like: 'What a poor Substitute for a Set of memorable Actions, is polished Alabaster, or the Mimickry of sculptured Marble,' (Hervey), or 'Lo! on each Tomb engrav'd the empty Name/ Of worldly Greatness levell'd in the Dust,' (Heber), is turning to stone with no thought of giving it voice, but only to make the sema a sign of its own inefficacy. Likewise a stone that roughly taunts its reader with sentiments like these: 'When thou readst/ The state of me/ Think on the Glass that runs for thee,' or 'Remember Reader when thou seest this stone/Who built for others now are built upon,' (Dingley), has ceased to expect an animating response from its spectator. In each case a refrain mocks the business of reading.

Although Wordsworth is to renew a sense of the 'communion of the living and the dead' that flourishes between the loving solicitations of the stone, and the 'affectionate admiration' of its reader, in his Essays on Epitaphs ${ }_{L}{ }^{11}$ the breakdown is fully evident in the scene at Archbishop Laud's memorial in Johnson's Vanity of Human Wishes: 'Around his tomb let 
Art and Genius weep,/ But hear his death, ye blockheads, hear and sleep.' These are examples of disfiguration, where the reader's prosopopeia made for the stone, and the stone's counter-apostrophe to the reader, are reduced to the stony prospects and retrospects of mortality. Such an undistracted contemplation of stone in the past and the future is analogous to the urgent desire of the organism to return to stone, of which repetition is always the symptom; so it is no surprise to find a kind of echolalia in these unconsoling epitaphs, what Debra Fried calls 'repetitious stalling': ${ }^{12}$

Shall we all die?

We shall die all,

All die shall we-

Die all we shall.

Even when the refrain is the result of passion rather than mockery, the same irrefutability of death draws utterance towards muteness. When David refused to be consoled by the pillar left behind by the dead Absalom, 'Thus he said, O my son Absalom, my son, my son Absalom! Would to God I had died for thee, O Absalom, my son, my son.' (II Sam, 18:33).

The most successful examples of quadrature are to be found in Scripture and literature rather than in tombs themselves, where the growing antagonism between the stone and its reader is fatal to figures. The literary examples however draw on the conventions and devices of tomb-inscription in order to rearrange them. An interesting reverse example occurs in Thomas Dingley's History from Marble, transcribed from an epitaph in Berkeley Church:

Where are thine accusers? Thus once spake he That wrote on dust to set the woman free; And where are thine accusers, may we ask, Writing upon thy dust. 'Twould be a task To find one that condemns thee. (98) 
The allusion is to John 8, where the woman taken in adultery is brought before Christ before being stoned to death in accordance with Mosaic law. In spite of repeated invitations by her captors to endorse the sentence, he stoops down, and 'with his finger wrote on the ground, as though he heard them not,' until his accusers get tired of waiting and go away, leaving the woman unstoned. In a gesture normally reserved to the exegete who announces the law as he traces its letters with his finger on the stone, Jesus uses his finger to detach the text of the law from the stones that would enact it, leaving the sinful seminal female body a margin between the two texts that stops her being turned to stone. When he puts the question, 'Woman, where are those thine accusers?' it is inflected with the inspiriting prosopopeia of a reader who lends his voice to stone figures in order to keep them in countenance. The question reappears on the Berkeley monument as just such a prosopopeia, triumphing in the absence of bad readers who would make nothing of stone but stone.

Of all 18th century illustrators, Blake seems to have been the most alert to the quadriform figures that can be fostered or erased by stone. In 'Prone on the lowly grave - she drops,' an illustration to Blair's The Grave, he shows a female figure clasping what Edward Young calls the 'unrefunding tomb', or rather the briar-bound mound which stands for unredeemed physical mortality in Blake's pictures. Here there is no sema, either sign or convenient stone, that is not indifferent to her case, and for the two potential readers there is nothing to read. Blake was aware that there could be too much of both, as in the title-page of Urizen, where the obsessive figure crouches beneath a pair of stone tablets, his feet on a book, while in his right hand he wields a pen, and in his left a burin, like a quadratarius gone mad. In his illustrations of Matthew's gospel, Blake shows a repetition of this destructive intensity, as the sepulchre is sealed with supererogatory stone by the order of the scribes, who carry the law embroidered on their garments, and who are very keen that no voice and no body reemerge from this tomb. The sequel is a fascinating reversal of the face-to-face roles of readers and stone-girt bodies, as Christ outside the structure comforts Mary Magdalene on the 


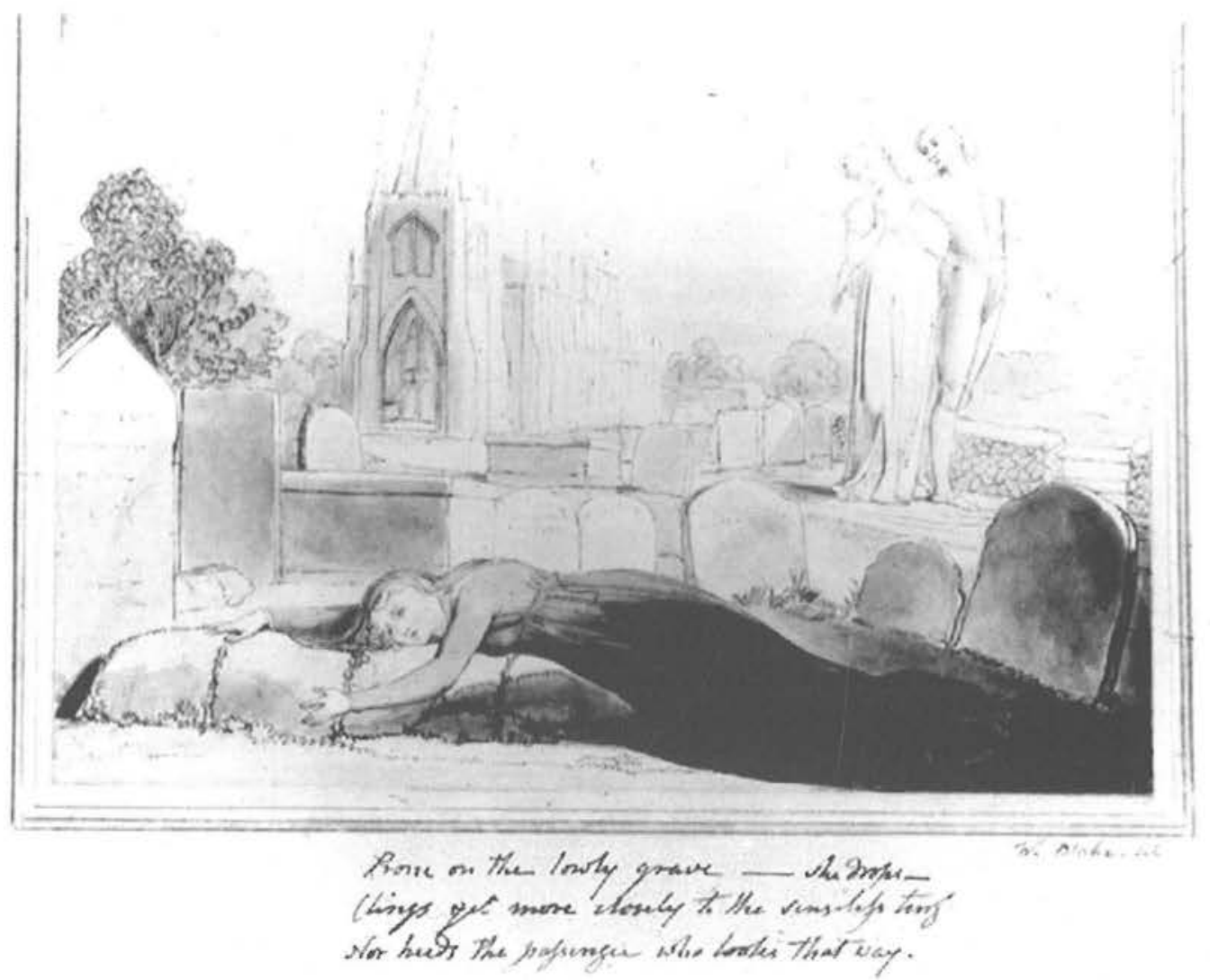

inside, as it were replaying his own resurrection by redeeming her from the empty stone.

I want to finish by showing how Blake follows Gray through the obliquities of the most famous graveyard poem of the century, Elegy written in a Country Churchyard. At first it seems to be written to mock the vanity of tombs, like Young's Night-thoughts or Hervey's Meditations: 'Can storied urn or animated bust,/ Back to its mansion call the fleeting breath!/ Can Honour's voice provoke the silent dust,/ Or flattery soothe the dull cold ear of Death?' But these rhetorical questions are destined to find an answer. The poet responds to the 
pathos of the rough grave markers of Stoke Poges churchyard which imparts to them a primitive legibility: 'Yet ev'n these bones from insult to protect/ Some frail memorial still erected nigh,/ With uncouth rhymes and shapeless sculpture deck'd,/ Implores the passing tribute of a sigh.' Three stanzas later, the poet is ready to read with full prosopopeia: 'Ev'n from the tomb the voice of Nature cries,' and in return to apostrophise his own tomb-reader with an imagined speech that posthumously takes place between a kindred spirit and a passing traveller: 'Approach and read (for thou canst read) the lay/ Grav'd on the stone beneath yon aged thorn.' The lay is the epitaph proper, addressed in the third person to the dead youth (alias the poet, alias Gray) who now sleeps in the bosom of his father and his God. This reflexive gesture is a superb re-establishment of the communion of the living and the dead, achieved as Gray oscillates, via his imagined readers, between the experience of writing and reading his own epitaph: or, in the family analogue discussed earlier, between being his father and his son. This is how Blake illustrates the three transitions. A sympathetic female figure traces with her finger the antagonistic legend, 'Dust thou art,' moderating like Christ, who wrote with his finger in the dust, the savage message of the stone. The stone bears the name William Blake, with an age that looks like 103. The next invitation to read is extended by the old shepherd to the young man as he points, apparently simultaneously, to an inscribed stone and a briar bound mound of earth that hides the decaying body. In the last plate a younger shepherd is leaning on his staff in such a way as to recall Poussin's famous picture, 'Les Bergers d'Arcadie,' and spelling out on the concealed plane of the tomb the identical text reproduced in the box above. In one sense the staff is like an elongated finger, doing the same job as the female finger that spelt out dust; in another sense it is like Gray's pen that turned his poem into a monument; and in another it is like the burin that cuts the plate, as if Blake were doing a clever self-portrait to answer his name on the previous gravestone. If this last hypothesis is plausible, then Blake moves himself from under the stone to the surface of the stone in a resurrective swerve that gains him about 75 years. By engraving his engraving of the grave, he makes an autoglyph that puts stone, 
writing and body into a configuration entirely missing from the enclosure of the Urizen plate. This is achieved by imitating the recursive relations of writer and reader in Gray's poem which depend in both instances on parallel transactions between the child and the parent-figure. Here it is the bosomed father; in the draft title-page for the Ode to Adversity it is a nursing mother, half-absorbed by tree-root and rock, who consoles the infant for all the cutting that has been going on above: just like the image of Niobe or Phrygian autoglyph whose ingrown characters define the name-proclaiming and face-giving virtues that thrive between stones.
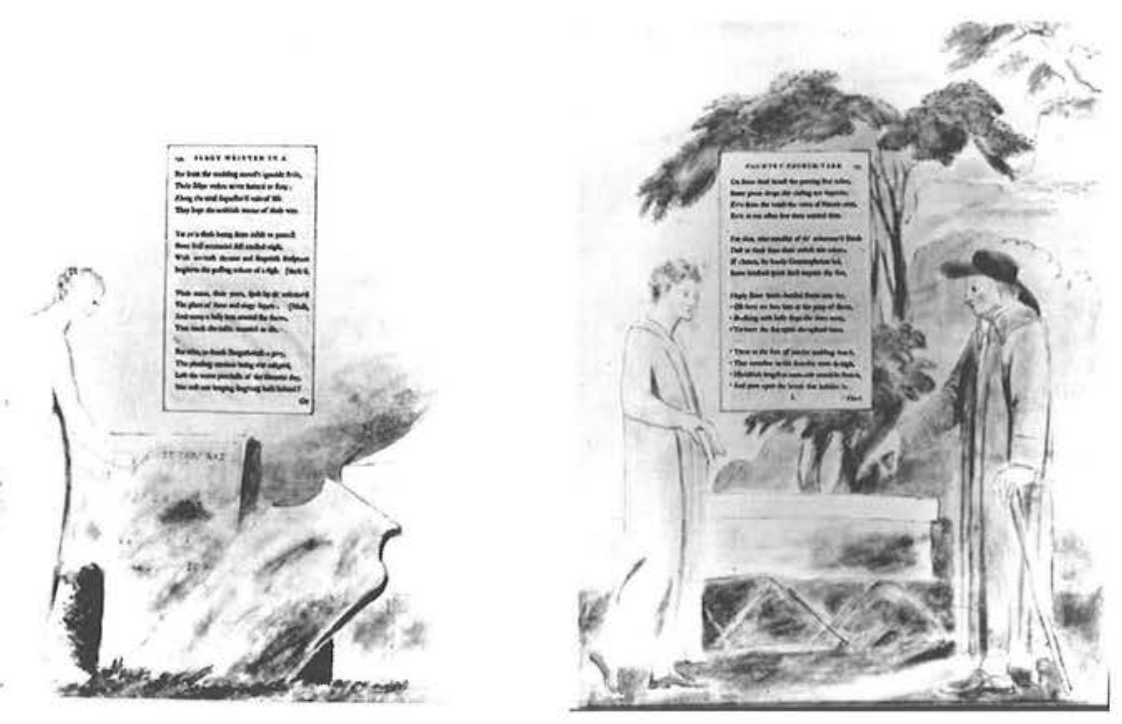

\section{Notes:} writing. 'An Essay on Epitaphs,' in Selected Writings, ed. Donald Greene (Oxford University Press, 1984), p. 96. 
See Marcel Detienne, 'L'espace de la publicite,' in Les Savoirs de l'ecriture en Grece ancienne, ed. Marcel Detienne (presses Universitaires de Lille, n. d.), pp. 49-50; and Jesper Svenbro, Phrasikleia: Anthropologie de la lecture en Grece ancienne (Paris Editions La Decouverte, 1988), pp. 23,44 .

Roger Caillois, Pierres (Paris: Gallimard, 1966), p. 18.

See Erwin Panofsky, Tomb Sculpture, (London: Thames and Hudson, 1964), figs. 25, 26.

Ovid, Metamorphoses, trans. George Sandys (Oxford, 1632; repr. Garland Publishing: Johns Hopkins University, 1976), pp. 222-3.

Neil Hertz, The End of the Line (Columbia University Press, 1986), p. 223.

Jacques Lacan, Four Fundamental Concepts of Psychoanalysis, trans. A. Sheridan (Harmondsworth: Penguin, 1979), p. 199.

The Prose Works of William Wordsworth, ed. W. J. B. Owen and Jane Worthington Smyser (Oxford: Clarendon Press, 1974), 2.66, 2.80. 